\title{
References
}

Allaart, J. H. 1965: The Lower Paleozoic sediments of Hall Land, North Greenland. Grønlands geol. Unders., Unpubl. rep., 11 pp.

Davies, W. E. 1972: Landscape of Northern Greenland. Spec. Rep. Cold Reg. Res. Engng Lab. 164, 67 pp.

Davies, W. E., Needleman, S. M. \& Klick, D. W. 1959: Report on Operation Groundhog (1958) North Greenland. Investigation of ice-free sites for aircraft landings, Polaris Promontory, North Greenland. 45 pp. Bedford: U.S. Air Force Cambridge Res. Lab.

Dawes, P. R. 1971: The North Greenland fold belt and environs. Bull. geol. Soc. Denmark 20, 197-239.

Dawes, P. R. 1976: Precambrian to Tertiary of northern Greenland. In Escher, A. \& Watt, W. S. (edit.) Geology of Greenland, 248-303. Copenhagen: Geol. Surv. Greenland.

Dueholm, K. S. 1973: Untraditional topographic mapping in central West Greenland. Rapp. Grønlands geol. Unders. 65, 26-28.

Dueholm, K. S. 1976: New instruments for geological photo-interpretation and mapping. Rapp. Grønlands geol. Unders. 80, 144-148.

Koch, L. 1920: Stratigraphy of Northwest Greenland. Meddr dansk geol. Foren. 5 (17), 78 pp.

Koch, L. 1929: Stratigraphy of Greenland. Meddr Grønland 73 (2), 2, 205-320.

Koch, L. 1932: Map of North Greenland, scale 1:300000, 18 sheets. Copenhagen: Geodetic Institute.

Lillestrand, R. L. \& Johnson, G. W. 1971: Cartography of North Greenland. J. Amer. Congr. Surveying Mapping, 31, 233-250.

Lillestrand, R. L., Johnson, G. W. \& Wells, D. E. 1968: Analysis of measurements made in northern Greenland during Project Nord - 1968. 99 pp. Minneapolis: Control Data Corp.

May, H. P., Reid, B. K. \& Dalton, A. D. F. 1972: Annex A, Survey report. In Joint Services Expedition, North Peary Land, 1969, 11 pp. London.

\section{Cambrian-Silurian studies in Washington Land, western North Greenland}

\author{
John S. Peel
}

The geological programme commenced in Washington Land during 1975 (Henriksen \& Peel, 1976) was continued at an amplified level during July and August 1976 when parties from the Geodetic Institute and the Institute for Surveying and Photogrammetry, Technical University of Denmark, joined three groups from GGU in a combined operation. The natural landing strip at the eastern extremity of Cass Fjord (fig. 10) again served as a base camp, but parties worked throughout Washington Land with support from a Greenlandair Charter Bell 204 helicopter periodically travelling north from Thule Air Base.

The party from the Geodetic Institute, Copenhagen, were primarily engaged in conventional triangulation and the establishment of positional coordinates using satellite-Doppler instrumentation, as a preliminary to possible remapping of North Greenland. The group from the Institute for Surveying and Photogrammetry, led by Keld S. Dueholm spent the 
Fig. 10. Washington Land, western North Greenland.

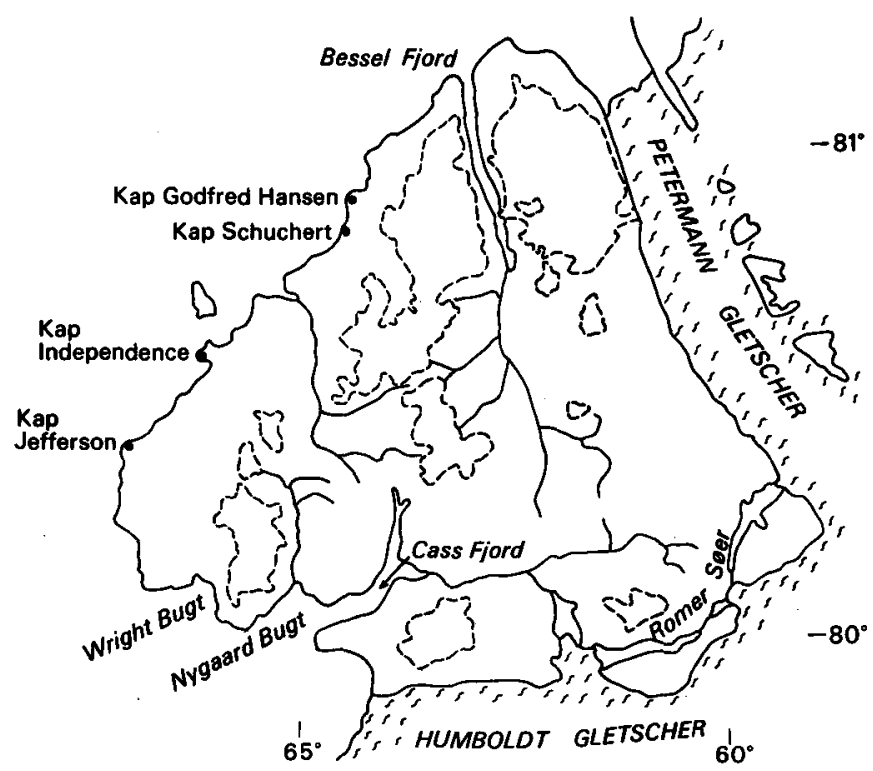

season measuring height and other ground control points in association with Dueholm's Danish Natural and Technical Science Research Councils' (SNF \& STF) sponsored project for photogrammetric/geological mapping.

John M. Hurst (GGU) studied sections in the Silurian exposed along the north-west coast of Washington Land (fig. 10), in order to elucidate the relationship between previously described, but poorly known, stratigraphic units. The presence of major unconformities representing periods of intense erosion between successive Silurian formations, originally postulated by Koch (1929a) and restated by Poulsen (1934), had been largely discounted during the last decade with the recognition of rapid and large-scale facies changes associated with Silurian carbonate mound complexes (see summary in Dawes, 1976). Consequently, Hurst returned to localities originally visited by Lauge Koch near Kap Jefferson, Kap Independence, Kap Schuchert and Kap Godfred Hansen to try and clarify Koch's concept of the stratigraphy.

- A lower unit of crinoidal calcarenites, dark limestones and graptolitic shales (the Cape Schuchert Formation sensu Koch, 1929a, but not Norford, 1972) was recognised at the three southern localities and may represent a continuous mappable unit. Overlying strata, variously referred to the Offley Island and Cape Tyson Formations by Koch (1929a), consist of a complex of carbonate mounds with associated breccia beds, and laterally equivalent shales, thin dark limestones and chert beds, with conglomeratic pulses derived from the mounds.

The sequence, as currently known, is considered by Hurst to be probably of Middle-Late Llandovery to Early Wenlock age.

Hans F. Jepsen (GGU) spent the months prior to the field season in photogrammetric interpretation of the geology of south-east Washington Land. Two pale marker horizons were followed throughout much of the area and several vertical faults with displacements of up to about $120 \mathrm{~m}$ were recognised. 
During the first part of the field season Jepsen visited this region, in the vicinity of the Rømer Søer (fig. 10), and was able to satisfactorily correlate the marker horizons with beds in the Kastrup Elv Formation and Cass Fjord Formation recognised in the Cass Fjord area during the previous year. In addition, clastic sediments with Scolithus and Cruziana were located under the dolomites of the Kastrup Elv Formation, the latter having been the oldest stratigraphic unit recognised during 1975.

In the second part of the field season Jepsen measured sections and mapped in the area south of the head of Bessel Fjord, readily recognising all the Ordovician formations established in the Cass Fjord area, up to the base of the Gonioceras Bay Formation (Middle Ordovician).

John S. Peel (GGU) started the season together with Jepsen in the Rømer Søer area and made collections of trilobites from the well developed Telt Bugt Formation. Subsequently; Peel examined Lower Ordovician - Upper Ordovician strata exposed along the north shore of Cass Fjord at Nygaard Bugt and Wright Bugt, continuing the cumulative section compilation of the previous year (Henriksen \& Peel, 1976).

Good collections were made from the Nunatami Formation, including previously unrecorded specimens of the gastropod Ceratopea which promise to be useful in terms of correlation between rocks of Late Canadian (late Early Ordovician) age in Washington Land, Peary Land and central East Greenland (Yochelson, 1964; Yochelson \& Peel, 1975). Evaporites, comparable to the anhydrite located in the Poulsen Cliff Formation (Early Ordovician) during 1975, were found in the lower beds of the Cape Webster Formation (Middle Ordovician) at Nygaard Bugt, although the greater part of the formation consists of pale weathering dolomites with siltstone partings. A single section measured through the Gonioceras Bay Formation - Cape Calhoun Formation at Wright Bugt promises to help unravel the somewhat involved stratigraphic nomenclature of Koch (1929b). Unfortunately, deterioration in the local weather prevented continuation of section compilation up into the Silurian, and the chance of a possible overlap with the Silurian sections measured by Hurst was temporarily lost.

\section{Acknowledgements}

The Royal Danish Air Force kindly arranged a parachute drop of badly needed fuel at Cass Fjord. Erik Arnholtz (Thule Air Base) and Jens Østergaard (Qânâq) provided valuable radio contact on a daily basis.

\section{References}

Dawes, P. R. 1976: Precambrian to Tertiary of northern Greenland. In Escher, A. \& Watt, W. S. (edit.) Geology of Greenland, 248-303. Copenhagen: Geol. Surv. Greenland.

Henriksen, N. \& Peel, J. S. 1976: Cambrian - Early Ordovician stratigraphy in south-western Washington Land, western North Greenland. Rapp. Grønlands geol. Unders. 80, 17-23.

Koch, L. 1929a: Stratigraphy of Greenland. Meddr Grønland 73 (2), 2, 205-320.

Koch, L. 1929b: The geology of the south coast of Washington Land. Meddr Grønland 73 (1), 1, 39 pp. Norford, B. S. 1972: Silurian stratigraphic sections at Kap Tyson, Offley $\emptyset$ and Kap Schuchert, Northwestern Greenland. Meddr Grønland 195, 2, 40 pp. 
Poulsen, C. 1934: The Silurian faunas of North Greenland. I. The fauna of the Cape Schuchert Formation. Meddr Grønland 72 (2), 1, 46 pp.

Yochelson, E. L. 1964: The early Ordovician gastropod Ceratopea from East Greenland. Meddr Grønland 164, 7, $12 \mathrm{pp}$.

Yochelson, E. L. \& Peel, J. S. 1975: Ceratopea and the correlation of the Wandel Valley Formation, eastern North Greenland. Rapp. Grønlands geol. Unders. 75, 28-31.

\section{Developments in petroleum exploration offshore West Greenland during 1976}

\section{Gilroy Henderson}

The first exploration well to be drilled within the concession areas granted offshore West Greenland in April 1975 reached its final depth of between 3500 and $4000 \mathrm{~m}$ in August 1976 and was abandoned as a dry hole. The well, Kangâmiut no. 1, was drilled in concession area 34 by the TGA-Grepco group with Total Gronland Olie A/S as operator using the dynamically positioned drill ship Pélican. The well was located about $120 \mathrm{~km}$ west of the mouth of Søndre Strømfjord and its coordinates were $66^{\circ} 09^{\prime} 00.92^{\prime \prime}$ N, $56^{\circ} 11^{\prime} 24.28^{\prime \prime} \mathrm{W}$. The water depth was $179 \mathrm{~m}$. This is the northernmost well to have been drilled in the marine areas between Canada and Greenland.

GGU was closely involved in the assessment of the application for permission to drill the well. During the drilling phase GGU representatives visited the location on several occasions. The Survey was also represented in the group under the Ministry for Greenland that followed the daily progress of the well. A full series of cuttings, samples and splits of the cores were sent to GGU and processing of these was started on receipt. After the drilling stopped the material and information received were evaluated in close collaboration with the operator.

Since this was the first well in a completely new area the results are of more than usual scientific and economic interest. All sample material, reports and interpretations stemming from the activities of the oil companies are confidential on receipt, but the concession agreements place certain limits to confidentiality. Concerning wells the relevant section in the concession agreement (subarticle $5803 \mathrm{~d}$ ) allows the Ministry for Greenland "to publish summaries of well data, including information on lithostratigraphic and chronostratigraphic boundaries and on zones which contain hydrocarbons, always provided that the publication shall not take place until 2 years after the completion of a well". This means that the first data on Kangâmiut no. 1 will become available in August 1978.

Only three of the six groups of concessionaires undertook deep-penetration seismic surveys in 1976, and the number of kilometres shot (under $1000 \mathrm{~km}$ net) was much less than in 